\title{
OF WARS AND WOES \\ A Chronicle of Lebanese Violence ${ }^{1}$
}

\section{Mordechai Nisan*}

In the subconscious of most Lebanese is the prevalent notion - and the common acceptance of it - that the Maronites are the "head" of the country. 'Head' carries here a double meaning: the conscious thinking faculty to animate and guide affairs, and the locus of power at the summit of political office. While this statement might seem outrageous to those unversed in the intricacies of Lebanese history and its recent political transformations, its veracity is confirmed by Lebanon's spiritual mysteries, the political snarls and brinkmanship that have defined its modern existence, and the pluralistic ethno-religious tapestry that still dominates its demographic makeup.

Lebanon's politics are a clear representation of, and a response to, this seminal truth. The establishment of modern Lebanon in 1920 was the political handiwork of Maronites - perhaps most notable among them the community's Patriarch, Elias Peter Hoyek (1843-1931), and public intellectual and founder of the Alliance Libanaise, Daoud Amoun (1867-1922). ${ }^{2}$ In recognition of this debt, the President of the Lebanese Republic has by tradition been always a Maronite; the country's intellectual, cultural, and political elites have hailed largely from the ranks of the Maronite community; and the Patriarch of the Maronite Church in Bkirke has traditionally held sway as chief spiritual and moral figure in the ceremonial and public conduct of state affairs. In the unicameral Lebanese legislature, the population decline of the Christians as a wholeMaronites, Greek Orthodox, Catholics, and Armenians alike- has not altered the reality of the Maronites' pre-eminence; equal confessional parliamentary representation, granting Lebanon's Christians numerical parity with Muslims, still defines the country's political conventions. The case of Lebanon as a uniquely Christian political phenomenon, in a Muslim Middle East weathering new challenges of a resurgent Islamism, is a powerful confirmation of Maronite uniqueness and exceptionalism. Moreover, Lebanon's social history also demonstrates that other groups, like the Druze and Sunnis, have come to terms with the fundamental importance of the Maronites to the Lebanese Republic, and have readily acquiesced in living together with them, in mixed villages and towns, despite their often conflicting visions of what Lebanon is and what it ought to be. Transitory episodes of tension, and even violent clashes, have not invalidated this truism. The Maronites seem to be the glue, the unifying chemical compound in the national laboratory of a multi-confessional, multi-ethnic state. Thus, the Shias would have never entertained the idea of a Sunni President of the Republic; nor would have the Sunnis relished the prospects of a Shia overlord. Indeed, all Lebanese communities seem to be in agreement that only a Maronite should be at the helm of state — or at a minimum, all concede a Maronite alone can be the least objectionable symbol of Lebanon's sovereignty. These Maronite Christians, descendants of the time-honored Phoenicians, are the historical repositories of the faith and wisdom of an ancient venerable people, celebrating values of liberty, multi-cultural intercourse

\footnotetext{
${ }^{1}$ Author's Note: The sources for a number of anecdotes, comments, and events in this article were shared by persons whose confidentiality and anonymity I am obliged to honor.

${ }^{2}$ See for instance Lyne Lohéac's Daoud Amoun Et La Création de L'État Libanais (Paris: Klincksieck, 1978).
} 
and universalist humanism over the millennia, radiating energy and creativity in all fields of human endeavor. ${ }^{3}$

There is no denying the Maronite "imperative" in the endurance and continuity of polyglot, cosmopolitan, multi-ethnic Lebanon. Conceding the Maronites' contributions to the state was a way of acknowledging a natural order of things; a way of taking heed of history's calling; an essential precondition for maintaining Lebanon's particularism and independence. Early on in the state's modern history, the Sunnis had wanted Lebanon to be part of Syria; and perhaps the Shias, while marginal and weak and wary of the Syrian Sunni majority and their Arabist historical narrative, would have concurred. ${ }^{4}$ Even the Greek Orthodox Christians would have readily succumbed to that political formula. Indeed, few were those who were willing to acquiesce in a Maronite-dominated Lebanon. But if there was to be a Lebanon - that being the single-minded aspiration of the Maronites - then their prerogatives had to be the optimal, nay the indispensable, axis of the new political order. It is worth noting that already in earlier centuries, Maronite communal primacy, eminent in its religious imprimatur, led many non-Christian Lebanese-like the Druze Abillamas and the Sunni Shihabs - to convert into Maronite Catholicism. ${ }^{5}$ This defiance of Islam was a special badge of Lebanon's unparalleled place in the Middle East.

The last third of the twentieth century witnessed volcanic eruptions of religious fanaticism and inter-communal warfare in Lebanon. This certainly sullied the more charming images of the country's past — as those from times when the Maronites, against great odds, established their national church, separate from Byzantium; or when the indomitable Mardaites, ancestors of today's Maronites, overcame the Syrian Umayyad menace at the end of the seventh century, and even exacted tribute from this illustrious Muslim dynasty; or when they later revolted against the Abbasid Caliphs toward the end of the eighth century. ${ }^{6}$ Defending their honor and their land throughout history, against Mamluks, Ottomans, and motley other adversaries, were also notable chapters of Maronite Lebanese distinction. And though not always crowned with resounding victories, their feats of bravery and resolve remain remarkable exploits in the annals of small peoples standing up to major powers. To wit, Maronite Patriarchs have traditionally rejected Ottoman firmans (royal decrees) confirming the community's ecclesiastical appointments-thus, boldly denying their suzerains' imperial authority and spurning Muslim overlordship.

The events in the 1970s illustrated the raw fact that the Maronites, without whom modern Lebanon would not have come into being, and would be ill-prepared to survive into the future, became nonetheless embroiled in a series of internecine fighting. These fratricidal frenzies were

\footnotetext{
${ }^{3}$ Charles Malik, Lebanon and the World in the 1980s, (College Park, MD: The Center for International Development, University of Maryland, 1983), 4-10.

${ }^{4}$ Kamal Salibi, A House of Many Mansions: The History of Lebanon Reconsidered (London: I.B. Tauris), Chapter 11, esp. p. 213.

${ }^{5}$ Theodor Hanf, Coexistence in Wartime Lebanon: Decline of a State and Rise of a Nation (London: I.B. Tauris, 1993), 55-56; and Labib Zuwiyya Yamak, The Syrian Social Nationalist Party: An Ideological Analysis (Cambridge, Mass.: Harvard University Press, 1966) Chapter 2. Interestingly, Shihab Muslims had earlier intermarried with Druze.

${ }^{6}$ Antoine Khoury Harb, The Maronites: History and Constants (Beirut: “The Maronite Heritage," 2001), 66-80.
} 
in addition and parallel to the Maronites' warring against foreign foes: Palestinians, Syrians, and an array of their domestic allies, from Druze to Sunnis to assorted varieties of likeminded political-ideological militias. Admittedly, intra-group fighting was also endemic among Shias belonging respectively to Amal and Hezbollah, as were Druze rivalries notorious between the Jumblatti and Arslani clans. But the Maronites' dissentions were, in their poignancy, more alarming and more noxious to Lebanon's very being. Unlike other communal tugs of war, the intra-Maronite struggles were no mere sectarian sideshows; their ramifications had profound disastrous effects on the country as a whole and on its raison d'être.

The Maronite descent into the inferno of violence during the 1970s assumed the ultimate form of political murder. What could account for this except unfettered family zealotry and power struggles among competing claimants to the community's leadership? The necessity of facing common non-Christian enemies was not sufficient to solidify Maronite unity. Intra-communal warfare took precedence over more important existential considerations - although pretense and protestation flurried about, claiming that resolving the rivalry among leaders was a prerequisite to successfully repel both local and foreign forces imperiling the Maronite body politic. It should be noted that political assassination targeting non-Christians was not unknown in modern Lebanon - with the murder of Sunni Prime Minister Riad al-Sulh in 1951, and Druze chieftain Kamal Jumblatt in 1977 being among the most notable. But the "war of the Maronite brothers" during the 1970s and 1980s highlighted the fact that neither ethno-religious kinship nor political imperative could silence the guns of hatred. ${ }^{7}$ Political competition free of violence was not, as such, exceptional among Maronite political contenders; the cordial rivalry between Émile Eddé and Bishara al-Khoury during the 1930s and 1940s was a supreme example of this benign political model. ${ }^{8}$ Cold-blooded murder within Maronite ranks, particularly from the 1970s onward, was a destructive departure from the norms of years past, and an odd shift toward political self-annihilation. For in the throes of internecine warfare, the Palestinians massacred Christians, the Syrians occupied Lebanon, and Iran subjugated the country to Shia Islamic domination. Meanwhile, the Maronites went on killing each other off in an orgy of barbarism and spite. We shall examine this sad chapter in Maronite history, and try to shed light on the dynamics behind it and the compulsions driving the minds and hearts of its actors-ambitious and vengeful men.

$* * *$

In the northern part of Mount Lebanon, where the Maronites and their ancestors have lived since time immemorial, predominant "feudal" families were also the prominent social and political elites. Among them was the Frangiyeh clan, led from the 1950s and into the early 1990s by Sleiman Frangiyeh. The Frangiyehs - whose patronym betrays evident "Frankish" origins - had their ancestral home in the mountain district of Zghorta; a "fortress-village" (as its Aramaic etymology denotes) standing sentry over the Sunni-Muslim Mediterranean port-city of Tripoli, itself dominated by the impressive remnants of Raymond de Saint-Gilles' twelfth century Crusader Castle. In 1970, Sleiman Frangiyeh was elected President of the Lebanese Republic.

\footnotetext{
${ }^{7}$ We note also the special case of the murder or "execution" with political motives of Antun Saadé in 1949, a Greek Orthodox Christian from Dhour al-Shuweir who founded and led the Syrian Social Nationalist Party; an organization which rejected the separate existence of Lebanon and advocated a secular Greater Syria.

${ }^{8}$ Meir Zamir, The Formation of Modern Lebanon (London: Croom Helm, 1988), Chapter 3.
} 
He would occupy that office until 1976, overseeing one of the most volatile and violent periods in modern Lebanon's history. Driven by the so-called "civil war" that erupted in April 1975 and the ensuing breakdown of government and the collapse of Lebanon's national army, Sleiman's son Tony organized and commanded the Zghorta Liberation Army; a regional Maronite militia intended to protect the Frangiyehs' fiefdom from potential Muslim intrusions. These Zghorta warriors, also referred to as the Marada, a name culled from the annals of the Maronites' Aramaic past, were notorious for their fierce Christian pride, their dogged courage, and their prowess on the battlefield.

But the challenges facing the Frangiyehs were not limited to Muslim adversaries. Undercurrents of Maronite rivalry clouded the family's station and hampered its domination of Northern Lebanon. This was so despite the establishment of the Lebanese Front in 1975, and later the creation of the Lebanese Forces (LF), both of which included central Maronite figures bringing together major Christian armed parties and political groups under a single unified command. Pierre Gemayel, from Bikfaya in the central Matn district of Mount-Lebanon, founder of the Kataïb (Phalangist) Party, had for some time aspired to expand and consolidate his leadership of the Christian Maronites throughout Lebanon-especially in the North, at the expense of Frangieh's Marada camp. Pierre's youngest son, Bashir, commanding the Lebanese Forces, shared his father's aspirations. The elder Gemayel had visited the Northern mountain district in 1974 brandishing a pretext of wanting to banish endemic political patronage and "family feudalism" from Lebanon's political culture. ${ }^{9}$ Targeted in this assault on "feudalism" was clearly the Frangiyeh clan's hegemony and the system of cronyism and clientelism that they had come to incarnate. The Kataïb seemed determined to foist their own programs and impose their own influence and vision in the economic, political, and military spheres - both on the local and national levels. On a broader strategic level, the Frangiyehs were aligned with Syria through personal relationships between Sleiman Frangiyeh and Hafez Assad, and between Tony Frangiyeh and Assad's younger brother Rifaat. All this stood in sharp contrast to the Gemayels' political course, with Pierre's son Bashir later becoming the symbol of an emerging association with Israel.

Local struggles fused at times with broader questions of Arabism, and floating, wider, Mediterranean identities rising and falling with the circumstances of varying times and tides. Issues of identity were always a tedious and often contentious preoccupation in Lebanese political discourse, frequently carrying important political implications. In the context of Middle East minority groups, Lebanon's Christians, who had never been enthralled with the idea of Arabism, had to be cautious in the face of Arab Islam and its agencies of nationalist compulsion and repression. The following anecdote offers some instructive political insight into this complex cultural phenomenon. In 1976, with Syria's military grip tightening around Lebanon, Rifaat Assad was invited by Tony Frangiyeh to visit with him at the family's summer palace in Ehden, high up in the mountains above Zghorta. In the heat of discussion, and in the spirit of the Baathist Party ideology (which, arguably, was the "cover" for the Alawite Assad regime in Damascus) Rifaat referred to Arabism as an all-encompassing identity and a ring of solidarity among all Middle Easterners, regardless of ethno-religious affiliation. This was perhaps in

\footnotetext{
${ }^{9}$ Richard Labévière, Majzarat Ehden [Arabic] (The Massacre of Ehden), Beirut: Dar al-Farabi, 2009), 130-32.
} 
response to Frangiyeh's reservations vis-à-vis Arabism - a general feature of Maronite political culture proudly ensconced in claims to a distinct, non-Arab, Lebanese particularism. That said, Arab nationalism's compulsory and suffocating notion that all Middle Eastern peoples were, or ought to become Arabs, can certainly sound a nefarious alarm to the proud Maronites, many of whom vehemently opposed their neighbors' intimations that they somehow are Arab, and if not, ought to become so. ${ }^{10}$ In a comfortable state of inebriation, after having consumed a good amount of Scotch, Rifaat indulged an earlier request of Tony's; namely that he speak freely and openly, as among friends. Rifaat would thus proceed with his intoxicated confessional confiding in his Maronite host that Arabism is symbiotically tied to Islam, and that Islam had effectively closed the door of Arabism shut to many Middle Eastern peoples. Rifaat would later tell his Lebanese interlocutors that: "ultimately, you [Christians] are okay as tolerated dhimmis living under Islam; but we [the Alawites] are khawarij [secessionists] who have left Islam. Our reward for apostasy is death: Muslims will not tolerate us the way they might do you; they will kill us as offenders of their religion.", 11

The pro-Syrian orientation of the Frangiyehs was not left without a counterpoint in Maronite circles. Etienne Sakr, also known by his nom de guerre "Abu Arz," founder and president of the Guardians of the Cedars Party (GOC) confronted Sleiman Frangiyeh with an alternate Maronite orientation: an association with Israel; another hated Middle Eastern minority, sharing the desperate struggles of other smaller minority peoples hunted down, molested, and persistently menaced by Arab Muslim dominance and nationalist intransigence. Abu Arz considered the Palestinian threat to Lebanon's national integrity to be a fatal blow to the country's existence. He told then President Frangiyeh "You have chosen the Syrian alliance and I have chosen the Israeli one; the winning course shall be invested to serve the interest of Lebanon; this in order not to place all our eggs in one basket." Frangiyeh's terse reply came as follows: "I trust you, go ahead, and may God be with you."

Another similar Frangiyeh-Sakr interchange would take place in February 1978, when a Syrian military unit had acted provocatively in defiance of Lebanese sovereignty, prompting a swift response by the Lebanese military, resulting in the killing of thirty-three Syrian soldiers near the Army Headquarters of Fayyadieh, in East Beirut. Frangiyeh was reportedly unhappy and evidently concerned with the heavy losses sustained by the Syrian Army. He expressed his alarm and anger privately to Abu Arz. This, at a time when history was feigning to record the gruesome realities of the Lebanese war, often willfully overlooking the destruction, mayhem, butcheries, mutilations, decapitations and rapes that Palestinians and Syrians were raining on innocent Lebanese civilians from the north of the country to its south. Abu Arz, whose opposition to the Syrians was legendary, ${ }^{12}$ reacted to the Fayyadieh events differently than Frangiyeh, asserting that "even if the Vatican itself were to fight the Lebanese Army, our support

\footnotetext{
${ }^{10}$ The idea that Maronites do not have the consciousness of being Arabs was expressed, when writing in the 1940s, by A.H. Hourani, Syria and Lebanon: A Political Essay (London: Oxford University Press, 1946), 97.

${ }^{11}$ The violent events in Syria during the popular uprising beginning in 2011 by the majority Sunni Muslims against the Assad regime contain the ominous possibility for Rifaat's fears coming true.

12 Mordechai Nisan, The Conscience of Lebanon: A Political Biography of Etienne Sakr (Abu-Arz), (London: Frank Cass, 2003), 49-52, regarding the retreat of Abu-Arz to Akoura high in the mountain of the Jbail district when Syrian forces, with the collaboration of Christian leaders, invaded Lebanon and entered Beirut in 1976.
} 
will incontestably go to our own military." Upon hearing this, Frangiyeh, a proud Lebanese patriot, reportedly fell silent and deigned no reply.

Like the quarrels that pitted Frangiyeh against Abu Arz, the Frangiyeh-Gemayel rivalry had initially been a purely political feud. However, it culminated in a dastardly June 28, 1978 massacre, during which Gemayel's Kataïb eliminated Tony Frangiyeh, his wife Vera, their threeyear-old daughter Jihane, and thirty other Marada partisans who had been at the family compound in Ehden. Even the family dog did not escape the carnage of that day. Samir Geagea, who led the attacking force, hailed from Bsharri, near Ehden. The two villages harbored a longstanding neighborly friction and simmering ancient feuds, which had now, against the political backdrop of the Gemayel-Frangiyeh rivalries, erupted in gruesome intra-Maronite slaughter. ${ }^{13}$ All the while, both before and after the massacre of Tony and his family, the Syrians pursued their unrelenting assault on Lebanon's Christian communities. Days after the events at Ehden, under orders from Rifaat Assad, the Syrians would proceed to bombard the Christian town of Deir el-Ahmar in the Bekaa Valley, and pound to a pulp the neighboring localities of Qaa and Ras Baalbeck in the Hermel district. The end result was the killing of some thirteen people, among them Kataïb fighters, perhaps to avenge Tony's murder. During the summer of 1978 Syria's "hundred days war" against Christian East Beirut would leave some six hundred civilians dead, and more than three thousand maimed and injured. Yet the Maronites, in mad fits of fratricidal power struggles, seemed unable to focus on the real enemy in their midst casting his crippling net of foreign occupation over their captive community.

In later years, Tony's surviving son Sleiman Jr. would become a member of the Chamber of Deputies in Beirut. A deputy himself much later in the early 1990s, Samir Geagea is reported to have often feared for his own wellbeing whenever left alone in the halls of government in the company of a man who still might be inclined to avenge the murder of his family. Beyond this, Bashir Gemayel who headed the Kataïb and commanded the Lebanese Forces until his own murder in 1982, had wanted to reconcile with Sleiman Frangiyeh. Abu Arz himself had advised Bashir to go straight to the former president and concede responsibility for the Ehden Massacre. In the morality of time-honored blood-feuds, an admission of guilt such as this - had it taken place - might have led to a sulh (reconciliation), wiped the slate clean, and helped heal old festering wounds. Unfortunately Bashir's own young life was cut short, never affording him a chance to act on Abu Arz's advice.

$$
* * *
$$

The Gemayels' war against the Frangiyehs in the North was followed by later battles against the Chamouns in the central part of the country. Camille Chamoun, President of Lebanon from 1952-1958 and founder of the National Liberal Party and its Tigers (Noumour) militia, was deemed another obstacle to Pierre Gemayel and his party's domination of the Maronites' political and military wings. Ever the seasoned statesman-he was nicknamed "the fox" in Lebanon's political parlance-Chamoun's political leanings at times seemed to tilt toward Syria.

\footnotetext{
${ }^{13}$ At the time of the attack, Tony did not have bodyguards in his home; rather, as village-clan solidarity functions, when the attack was imminent and began, students and neighbors/friends came running to the home. Eliezer (Geizi) Tsafrir, Plonter [Hebrew] (Labyrinth in Lebanon), Tel Aviv: Yediot Achronot, 2006), 59, offered a different description.
} 
He traditionally viewed Israel with hostility, ${ }^{14}$ although his ostensible Syrian leanings might have been driven more by pragmatism and the exigencies of Lebanon's confessional politics, than by sheer conviction. Shunning Israel publically was a supreme form of Christian-Lebanese statecraft, aimed at mollifying and appealing to Lebanon's Muslims, many of whom may not have taken kindly to the prospects of a Maronite-Israeli alliance. Back in 1958, as president of a republic convulsed by conflicts with Nasserite Arabists, Chamoun was grateful to receive weapons from Israel to supply his embattled military. Camille's dashing son, Dany, who did open up a line of communication with Israel in the early 1970s, would however disclose to his Israeli friends, (no less to those in the Mossad who coordinated Israel's early contacts with the Christian militias,) that "you Israelis are [mere] instruments for us. If you don't help us, we will just turn to the Syrians." "15 Might this have been a neophyte's slip of the tongue, or the shrewd artifice of a seasoned statesman? Either way, the Maronites' political vicissitudes would ultimately lead Dany's father Camille to meet with Prime Minister Yitzhak Rabin in the Bay of Jounieh in 1976. Additional visits would ensue in later years, and in August 1978, the elder Chamoun, racked by heavy Syrian artillery, would find himself beseeching Prime Minister Menachem Begin to save the Christians from near annihilation. It was no small feat to make out who were one's dangerous enemies and who might turn out to be the real friends in the quicksand of Lebanon's shady political culture.

The bloody showdown between the Gemayels and the Chamouns was the culmination of their respective militias' skirmishes over the early years of the Lebanon war. On July 7, 1980, the Kataïb headed by Bashir Gemayel went on a murder spree against Chamoun's Tigers Militia Headquarters in Safra Marina, north of Beirut. About a hundred men from Dany Chamoun's forces were eliminated in the heat of those clashes, forcing the Tigers to disband, and Dany Chamoun to seek exile in London. One Tiger brigade survived, however, eventually relocating to Muslim West Beirut, and later aligning with a Palestinian unit. Something very disturbing in the Kataïb's DNA seems to have never taken kindly to diversity of perspectives, willy-nilly undermining consensual Christian unity as a prerequisite to Lebanon's national welfare. With the bloody Phalangist bludgeoning of two rival Maronite forces, it was not unreasonable for the Guardians of the Cedars Party (GOC) to fear turning up as the next name on the killer's hit list. Indeed, often times Abu Arz felt as if being issued veiled threats by the Gemayels, and when on January 29, 1990 an invading force under orders from Samir Geagea invaded his Beirut home and placed him under house-arrest, Abu Arz's premonition proved justified. He got away with his life but was forced to flee the country, later returning to the southern part of Lebanon where he would set up his headquarters at Sabbah, just west of Jezzine.

Yet the sinister menace of murder didn't end there. Pierre Gemayel's attitude toward Saad Haddad, who commanded the South Lebanon Army, which came into being in 1976, further magnified the Phalangists' arrogance and hunger for power. Abandoned by their state and their military, many southern Lebanese, and especially the Christians among them, were subjected to armed Palestinian gangs that bullied and terrorized them and impinged on their freedoms and

\footnotetext{
${ }^{14}$ David Kimche, The Last Option: After Nasser, Arafat and Saddam Hussein (London: Weidenfeld \& Nicolson, 1991), Chapter 9; also, Reuven Ehrlich, Be-S'vach Ha-Levanon 1918-1958 [Hebrew] (The Lebanon Tangle) (Tel-Aviv: Ministry of Defense, 2000), 236, 367, 385-6, 467-8.

${ }^{15}$ Thomas Friedman, From Beirut To Jerusalem (London: Fontana, 1990), 139.
} 
national prerogatives. Turning to Israel for moral and military assistance, the South Lebanon Army received arms and supplies and many other gestures of friendship. ${ }^{16}$ Yet Pierre Gemayel was excessively hostile toward Haddad, perhaps because the officer from Marj'ayoun had been politically affiliated with Camille Chamoun. Once, when a group of Lebanese Christian leaders visited Damascus in 1976, Hafez Assad remarked: "How could you not condemn the political alliance of Saad Haddad with the State of Israel?" Pierre Gemayel's retort then, came as follows: "Vous avez raison M. Le Président. Il faut le tuer." ${ }^{, 17}$ Even Sleiman Frangiyeh, a committed ally of the Assads, dared think and speak otherwise: "if I was in his [Haddad's] place," he said, "I would do the same thing"- that is to say, he would have turned to Israel for assistance.

$$
* * *
$$

A central irony of the intra-Maronite struggles was the fact that the community fought its own, while others, the Syrians and the Palestinians, maintained their systematic assault against them. Instead of rallying around the Lebanese flag and forging unifying bonds of solidarity against foreign foes destroying their country, the leading Maronite families pursued their own private wars, giving rein to self-destructive fits of jealousy and competition. Having for long been a bold exception to many historical norms in the Middle East, one of which stipulating Christian inferiority within the broader realm of political Islam, the Maronites also cast off a basic sociological rule requiring strict group cohesion in the face of external threats.

During the decade of the 1980s, political assassinations became the weapon of choice in the arsenal of Syria's occupation of Lebanon. Activating one of its sleeper-agent, Habib Tanios Shartuni, a wayward Maronite member of the Syrian Social Nationalist Party, the Syrians eliminated Lebanon's president-elect Bashir Gemayel — another defiant figure in a long list of Lebanese leaders daring to stand up to Syria's sinister pax Syriana. On September 14, 1982, a bomb detonated by remote control brought down sections of a building housing the Kataïb Party's Ashrafiyeh headquarters, taking the life of those inside, including Bashir Gemayel and a number companions and ordinary citizens then present. The Phalange-Israel connection was a major motivating factor in the killing of Bashir. Over the years, Syrian intelligence services were suspected to have been behind the murders of many more Lebanese personalities defying their hegemony, among them: Selim al-Lawzi (1980), editor of al-Hawadeth magazine; Riyad Taha (1980), president of the Lebanese Press Association; Father Philippe Abou-Sleiman (1982) from Aley; Sheikh Halim Taqieddin (1983), head of the Druze religious court; Sheikh Hassan Khaled (1989), the Sunni Mufti of Lebanon; and René Moawad (1989), then president of Lebanon. Moreover, Pierre Gemayel, Camille Chamoun, and Druze leader Walid Jumblatt, would also become targets of assassination, with the bounties on their heads fluctuating depending on their public attitudes and statements vis-à-vis Syria.

$$
* * *
$$

The name of Michel Aoun, a Maronite from a southern Beirut neighborhood, evokes conflicting reactions among many Lebanese. As the Commander of the Lebanese Armed Forces who fought off the Palestinians and Syrians at Souk el-Gharb in 1983, General Michel Aoun became Acting

\footnotetext{
${ }^{16}$ This abruptly ended with very discordant chords when Israel precipitously carried out its military withdrawal from southern Lebanon in May 2000, compelling SLA soldiers and families to flee for their lives into Israel.

17 'You are right Mr. President. It is necessary to kill him'.
} 
President of Lebanon and head of a caretaker government in unusual circumstances in 1988. Soon after taking office, Aoun declared Lebanon's "war of liberation" against the Syrian occupation, only to be crushed by a superior Syrian war machine, forcing him into exile in France in October 1990. Fifteen years later, Aoun would return to Lebanon, presumably with Syria's stamp of approval. He would subsequently sign a "Memorandum of Understanding" with Hezbollah, exacerbating the already deep divisions racking the Maronite community, and situating Aoun himself as a central polarizing figure in Lebanese politics. To this day Aoun arouses feelings of resentment and dislike among many elements of Lebanese societyespecially among the Christians, and particularly within the Maronite community.

In January 1990, the Lebanese Forces/Phalangists led by Samir Geagea fought a fierce and futile battle against the Lebanese Army commanded by Michel Aoun. It was a classic case of state and non-state actors drawing swords: would the state (represented by Aoun) prevail, or would Geagea's Lebanese Forces succeed and establish a new republic in its own image? Maronite fratricide seems to have always resorted to these kinds of atavistic struggles; bickering between two brothers bereft of a reasoned father figure to contain their vernal rage, would soon degenerate into violent sibling rivalries. Geagea had accepted the Syrian-imposed Ta'if Agreement signed in Saudi Arabia on October 22, 1989. The accord, which was meant to end Lebanon's civil strife, reduced the powers of the Maronite President and diminished Christian parliamentary representation. It also introduced a constitutional preamble whereby Lebanon, for the first time in sixty-nine years of statehood, would come to be defined as an entity "Arab in identity," joined at the hip with Syria - a "sisterly country" as it were, with which Lebanon was now enjoined to partake of "a special relationship." Aoun opposed Ta'if as a political sell-out of Lebanon's independence and a dilution of its special character. This stood at the basis of the fall out between him and Geagea. Consumed in his hubris, Aoun believed that a brief "24-hour war" between his Lebanese Army and Geagea's Lebanese Forces would conclude with him still Prime Minister sitting in the Baabda Presidential Palace, and would perhaps lead to his inauguration as the next President of a new Lebanese Republic free from Syrian domination. However, the planets, it seems, were lined up in Syria's favor and international circumstances played into Syria's hands. With Syria aligned with U.S.-coalition forces assembled against Iraq, following Saddam Hussein's invasion of Kuwait, the United States suddenly became more inclined to lend support to Syria's long-standing interests and ambitions in Lebanon. Thus, Washington would issue its proverbial "green light," after which Assad would move into the "free areas" of Lebanon, snuffing out Aoun's ephemeral and vainglorious "liberation" project. In the end, on October 13, 1990, as Geagea and Aoun had for weeks been slugging it out in the regions outside of Syria's control, the Syrian military proceeded to soften both camps by systemically shelling their main civilian conglomerations and military centers. Heavy tolls in human losses and material destruction were exacted; Lebanon's economy collapsed; its Christian population was brought to its knees; and the whole of the country, in tatters, was forced into the Syrian sphere.

But the fifteen-year-old Lebanese war suddenly came to a halt. The Syrian "big brother" smashed the regular Lebanese army (as well as Geagea's Lebanese Forces), tortured and murdered in cold blood captured soldiers - in one instance, at Dahr el-Wahsh, shooting eighty prisoners of war in the head and mouth with hands tied behind their backs - and forced Aoun out of the country. 
Yet, perhaps Aoun's humiliating defeat and Lebanon's dreadful loss might have been averted had the "Israeli card" been played with greater consistency and efficacy. Aoun would claim over the years, and not without puff and swagger, that he never dealt with Israel or received aid from her. This would presumably contrast with the Gemayel Phalangists, like Samir Geagea, Fady Frem, Elie Hobeika, and many others, who readily maintained secret ties with Israel and underwent military training south of Lebanon's border. Pierre Gemayel himself hosted a visit by Israeli Defense Minister Ariel Sharon in his Bikfaya home in 1982. This was allegedly not the way of Aoun, neither in 1990, nor previous to that. Nonetheless, at Souk el-Gharb, in 1983, Aoun asked for Israeli aerial intervention on a battlefront against the Syrians. After he had assured the Israeli officer-in-charge that none of the local Druze populations would be targeted, Israel accommodated Aoun's request, quickly and effectively. This kind of coordination would be repeated a few months later. In facing the dire Syrian challenges in 1990, Aoun was interested in Israeli (and Iraqi) assistance, frantic with fear of a Syrian invasion of the Baabda Palace, the seat of his government, which would effectively put an end to his "liberation war." Those were harrowing days interspersed with emotionally uplifting moments of hope, and popular support for General Aoun.

In one instance, in the heat of battle, and at the insistence of Aoun himself, Abu Arz would send the Guardians of the Cedars' chief of operations to Cyprus in order to meet with Israeli officers and find a way to lend support to Aoun's embattled troops. The meeting was a positive one, leading to increased coordination between Aoun and Israel, with the GOC acting as intermediaries. However, Aoun was, subsequently, approached by the Syrians who sought to cut him a deal-provided he ended his ties with Israel. He agreed. But then the Syrians came to beat his "war of liberation" to a pulp of dust and tears and blood. There was little sign of Aoun's political acumen (or military skill) in these deceptive and ultimately losing dealings. In the end, the Israelis flew a single plane to neutralize Syrian aerial sorties against the Lebanese army. But Aoun never acknowledged any of this, denying the faintest hints to any connection with Israel. Yet he had no compunctions stating in a press conference at the Baabda Presidential Palace that he "would relish being a minor officer in the great Syrian army." Therein lay the essence of Aoun's political gambit: challenging Syria on the one hand; flattering and capitulating to Syria on the other - two sides of a man consumed by an unbridled (and shameless) hunger for power.

$* * *$

While Michel Aoun's war against Syrian hegemony was most poorly prosecuted, Samir Geagea's own war against Lebanon's state institutions was an act of utter folly. To date, it was the worst spectacle of intra-Maronite bloodshed yet experienced in the long drama of Lebanon's slide into self-destruction. And then, another grisly addendum would be affixed to the primary script: on October 21, eight days after the Syrian assault on Aoun's forces, the National Liberal Party leader and commander of what remained of the battered Tigers militia, Dany Chamoun, along with his wife and two small sons, were murdered in their Beirut home. Dany had, like Abu-Arz, chosen to side with Aoun in his battle against Geagea's Lebanese Forces. Now Michel Aoun was out of the picture and Dany Chamoun lay dead. It is more than painful irony that the Christians of Lebanon, who unlike other Near Eastern Christians defied Islam and dhimmitude, 
carried weapons and challenged Muslim adversaries on the battlefield and in the marketplace, were now recklessly pointing their daggers at each other's throats.

Chamoun's murder was initially blamed on the Syrians, but the suspicion soon turned to Geagea, who was ultimately found guilty in a Supreme Court decision, landing him multiple life sentences. ${ }^{18}$ In the Ehden Massacre of 1978, the Phalangists left Tony's son Sleiman alone. He survived and grew into a leading political figure and a deputy in the National Assembly. He also became a sworn enemy of Samir Geagea's, whom he still presumed to have murdered his father. In the 1990 Chamoun murder, both of Dany's sons were killed, arguably making certain they would never grow up to avenge their father's death. On the political plane, following his acceptance of the Ta'if Agreement, Geagea's Lebanese Forces received two Ministerial portfolios in the first "post-war" Cabinet. Yet the new Prime Minister, Dr. Selim al-Hoss, had been close to Dany Chamoun, and this in itself might have posed a serious challenge to Geagea's political future in the new era. The Phalangist militia was dismantled after Ta'if, and Geagea's political influence was rendered unremarkable without a military arm. The removal of Dany Chamoun could, therefore, be perceived as a way to enhance Geagea's political ascendency in a new political era.

As it turned out, Geagea ended up in jail in 1994 - the only Lebanese militia leader to be put on trial for crimes committed during the war. His many political felonies and violent wartime transgressions included: his 1983 "mountain war" against the Druze in the Shouf; his attacks against the Sunnis of Sidon in 1984; his clash with Phalangist rivals like Elie Hobeika over leadership of the party 1984-86; and the accusations leveled against him for allegedly having been behind the 1987 assassination of Prime Minister Rashid Karami. But in the wider scheme of things, Geagea's crimes did not seem more outrageous than the abominations of others in the conduct of the Lebanon war. However, the official reason for Geagea's imprisonment was not the killing of Dany Chamoun. Nevertheless, Geagea was arrested and tried on-most probably trumped up — charges that he had masterminded the 1994 bombing of the Church of Sayiddet elNajet in the locality of Zouk, north of Beirut; an incident that left nine people dead. Geagea would end up incarcerated in solitary confinement, and under very difficult conditions, for the next eleven years.

Although Geagea was acquitted in the church case, the idea that he might still have been responsible for the bombing, aiming at fomenting inter-sectarian tensions (by attempting to blame Lebanese Muslims for the crime) was not completely inconceivable. A committed proponent of Lebanese Christian autonomy, Geagea at the time could have used LebaneseChristian popular support for the establishment of a separate Christian canton, free from Syrian domination and safe from Muslim demographic and political encroachments.

A chronology of events unraveling in nearby Syria a mere month before the church bombing could offer some insight into the circumstances that may have led to the hasty manner in which Geagea was arrested, put on trial, and handed down multiple death sentences-later commuted

\footnotetext{
${ }^{18}$ It should be noted that Geagea's trial was orchestrated by a Lebanese regime wholly subservient to Syria, and the integrity of which is not above suspicion. The Lebanese parliament passed an amnesty bill in July 2005 and Geagea was set free.
} 
to four life sentences. On January 21, 1994, Bassel Assad, elder son and heir-apparent to Syrian president Hafez Assad was killed in a fatal car crash on the highway to the Damascus Airport. Devastated by the loss, the Assads retreated in mourning to their ancestral mountain village of Qardaha in northern Syria. Geagea, along with a number of Lebanese dignitaries, headed a delegation to Syria to offer condolences and comfort the family of the deceased. Raji Abdo, member of the Amn al-Askari (Military Intelligence) of the Lebanese Forces and - unbeknownst to Geagea at the time - a close associate of the Syrian regime, was part of the Lebanese delegation traveling to Qardaha. Assad received his well-wishers warmly. But this did not sit well with hardliners within the Lebanese Forces, many of whom castigated Geagea for having walked into the lion's den, offering condolences to an archenemy and a murderer of many a Lebanese. Geagea's response, within an earshot of Raji Abdo, came simple and befitting of the occasion: "Let [Assad] lose another son, and I will go to Syria every day." Soon thereafter Geagea found himself incarcerated, and Assad would issue a terse warning against the slightest notion of setting him free: "if you let him out of jail," he warned his Lebanese vassal — the Syrian-appointed President of the Republic, Elias Hrawi- “you will take his place.” In the thicket of Middle Eastern political backslapping and backstabbing, your friend may become your enemy, and your enemy may one day become your best of friends.

Shortly before his fortunes started turning, Geagea had also come to Tel Aviv, to meet there with Abu Arz and South Lebanon Army commander General Antoine Lahad. The Israelis had wanted to reconcile Abu Arz and Geagea, so that the leader of the Guardians of the Cedars would one day safely return to his home in Beirut. During that encounter, Abu Arz broached the topic of the church bombing; but no clear answer was forthcoming from Geagea's side, except perhaps intimation that it might have been Hezbollah's handiwork. Truth be told, Hezbollah did not make a habit of attacking churches; not in Beirut and not in southern Lebanon following the Israeli withdrawal and the dissolution of the SLA. But in Lebanon nothing is always clear-cut, and nothing is always determined in measurable standards.

$* * *$

Ghastly use of violence was not, it seems, foreign to the life of Elie Hobeika; another Maronite and a senior Phalangist leader with unsavory leanings and a dark history of internecine powerstruggles, murderous outbursts, manipulations, and illicit activities. Hobeika was a central figure in the Ehden massacre, and is often mentioned in reports of the 1982 Sabra and Shatila Palestinian refugee camps massacres in Beirut. This notorious act of sordid Lebanese vengeance was instigated by the murder of President-elect, Bashir Gemayel, on September 14, 1982; a catastrophe - at least from the Maronites' perspective - that ignited a storm of fury against the Palestinians, though the Palestinians had no hand in the assassination. But having rained unspeakable mayhem, death and indignity on the Lebanese during seven long years of war, the Palestinians seemed like an easy and convenient target for afflicted Maronites bent on revenge. Foremost were the Palestinian massacres of Christians - the imprint of aliens in the Land of the Cedars. The Palestinians had flagrantly chosen Lebanon as a springboard to "liberate Palestine," thereby twisting Lebanon's identity and stunting the fulfillment of her destiny as a country of liberty, openness, and culture. The Lebanese took the Palestinians in as refugees in 1948. But soon the destitute guests turned on their hosts, and the Palestinians slaughtered Lebanese Christians at, among other places, Beit Mallat, Ayshiyeh, and Damour (where it is reported 
Hobeika's fiancée was murdered in 1976.) The events at Sabra and Shatila were born in a historical context, which the Lebanese (unlike a world oblivious to their plight and uncritically committed to that of the Palestinians) understood and experienced. Hobeika was never put on trial for his role in the notorious episode.

The violence that Hobeika used against Maronite opponents within Phalangist circles, as in the intifada that was fought against Geagea in the mid-1980s, and his nefarious personal indecencies, were not, it seems, what brought him to his violent end. ${ }^{19} \mathrm{He}$ was killed in January 2002 in the Hazmiyeh neighborhood of East Beirut when, according to one report, his boobytrapped car exploded - or, according to another version, when a parked vehicle filled with a large dynamite charge detonated as his car passed nearby. The likely perpetrators of the blast were Hezbollah elements in the service of Iran; a payback, as it were, for Hobeika's alleged involvement in the kidnapping and elimination of four Iranian diplomats in July 1982 (the Iranian government claims the diplomats were transferred to Israel, though other reports suggest their remains were buried near Jeita, above the Bay of Jounieh. ${ }^{20}$ It should be noted that kidnapping Christian opponents for ransom was not unusual for Hobeika and his men-so applying those skills to foreign nationals might not have been such a far-fetched possibility. The Lebanese Forces, it is believed, had kidnapped the Iranians at the Barbara checkpoint on the coastal highway in northern Lebanon during a period of high tension. For Lebanese Christians, the Iranians of the Islamic Republic were an enemy target whose neutralization at the time had been justified. At any rate, Hobeika who received his military and intelligence training in Israel later transferred his skills and allegiances to the Syrians, who awarded him handsomely with a ministerial post in the post-war Lebanese government. The whole Iranian affair was thus laid to rest and Hobeika's involvement forgotten. But his assassination many years later re-opened the Iranian file (even if only for a brief moment) and closed the circle as it were.

$* * *$

The February 14, 2005 assassination of Prime Minister Rafiq Hariri, the well-known Sunni Lebanese politician-billionaire, was not without its Maronite component in the complex Lebanese puzzle of sectarian politics. The international Special Tribunal for Lebanon, which investigated the murder of Hariri and twenty-one other people in downtown Beirut, fingered Syrian President Bashar Assad (who allegedly commissioned the murder,) and Hezbollah (which purportedly executed it.) The assassination took place at a time when Hariri was admittedly no longer in office. Having completed two terms as prime minister from 1992-98 and 2000-04, he became more outspoken in his opposition to the Syrian occupation of Lebanon once he was out of office. Indeed, Assad accused Hariri of having been the single most influential political personality to have brought about UN Resolution 1559, which, in September 2004, called for the withdrawal of all Syrian forces from Lebanon. Assad was known to have directly threatened Hariri with murder - mere months before the massive blast that pulverized his car convoy and took his life in downtown Beirut.

\footnotetext{
${ }^{19}$ About Hobeika, see Robert M. Hatem, From Israel to Damascus (Pride International Publications, 1999).

${ }^{20}$ Another theory for Hobeika's murder relates to him trying to reactivate his relationship with foreign intelligence, including the CIA. His elimination and that of his colleague deputy Jean Ghanem in the same year was possibly about severing any potential link with the United States.
} 
The Maronite element in these gruesome events involves Lebanese President Émile Lahoud, in office from 1998-2004, whose term was unconstitutionally extended through Syrian diktat until 2007. Hariri served as prime minister for most of those years, and it was public knowledge at the time that the two men did not get along well. Hafez Assad had initially imposed Hariri upon Lahoud. Abd al-Halim Khaddam, Syria's Foreign Minister and Deputy President, had supported this move. Beyond this, the two men - Hariri and Lahoud - were on different political sides: Lahoud sided with Hezbollah/Iran while Hariri was aligned with the Saudis. Here was the destructive Sunni-Shia schism playing itself out in Lebanese politics. In brief, Bashar Assad wanted to get rid of Hariri, and Émile Lahoud wanted this no less than his Syrian president; both believing that they would be secure - and Syria more snuggly installed in Lebanon — with the removal of Hariri from the political scene.

In the immediate aftermath of Hariri's assassination, Lahoud made sure the crime scene was wiped clean, erasing all evidence that could have led to the perpetrators, or to those who had commissioned them. But there was evidence that would simply not go away; namely a telephone conversation shortly after the blast, between Lahoud himself and the alleged assassins, recorded by a British telecommunications outfit based in Cyprus. Lahoud, who has a lisp and is unable to "roll" his Arabic "R", was recorded gloating in his distinctive gurgling "French accented 'Rs"”; "we are rid of this shit [Hariri]," he was reported to have said. Thus, if this turns out to be true, a Maronite President will have collaborated in the execution of a Sunni Prime Minister. Although a clear violation of Lebanon's delicate "sectarian concordat," this would not necessarily reflect sectarian animosity, but rather the violence attending political rivalry in war-torn Beirut. Tending to a fragile republic subjugated to foreign intervention, and healing the Christian community of its internal wounds, were not, it seems, part of the work-manual guiding Maronite politicians in those terrible days.

Following the Hariri assassination, the Syrian killing machine targeted other Lebanese public figures who spoke out against Syria — most especially Christians. The list included Samir Kassir and Gibran Tueini, George Hawi and Pierre Gemayel (son of Amin), and others who were killed, maimed, or injured. This grim reality demonstrated, as former Deputy Prime Minister Elias Murr said, that the Lebanese were trapped by Syria into either becoming a slave or ending up a corpse. ${ }^{21}$ Émile Lahoud was an accomplice of the Syrian occupation of Lebanon, though he was far from being the only Maronite politician to choose the path of treason to the Lebanese fatherland and the Lebanese people.

$* * *$

The collapse of Lebanon beginning in the 1970s was the combined handiwork of Palestinians, Syrians, and Iranians, who bludgeoned the Lebanese into submission, occupied their country, trampled their national identity, degraded and Arabized their education, hijacked their free media and their libertine political and cultural conventions, and in sum robbed them of their dignity and freedom. Yet, the foreigners were not alone in their pernicious destructive conduct; native Lebanese were also avid participants in this orgy of violence and vandalism. To wit, a number

\footnotetext{
${ }^{21}$ Murr had also served as Deputy Defense Minister who, it was reported by WikiLeaks, had advised Israel not to attack Christian areas in its war against Hezbollah. He was also the son-in-law of Émile Lahoud.
} 
of prominent Maronite leaders willingly partook of political corruption and fratricidal warfare, begetting inter and intra-communal hatreds, and provoking pandemics of demoralization, mass exodus, and sweeping population movements. This is not to absolve other Lebanese communities - Shias, Sunnis, and Druze - from collective responsibility. Still, the onus was on the Maronites, and the Maronites should have known better.

Saïd Akl, the great poet of Lebanon, claimed to possess the solution to his country's ills. With his trademark candor, bordering on the provocative, he explained that "if the Christian leader was a saint, you could Christianize [all of] Lebanon." 22 Akl's is a profound statement on the country's mystique and the spiritual qualities of its people. Parallel to this notion conceding Lebanon's Christian core is Abu Arz's own affirmation that "one cannot be a great Lebanese if one is not a good Christian." ${ }^{23}$ This is pushed a step further by Charles Malik no less. A Greek Orthodox Christian from the Koura district of Mount-Lebanon and co-author of the United Nations' Universal Declaration of Human Rights who also served as Chair of the UN's Human Rights Commission, Malik maintained that one has to be Christian in order to be Lebanese. ${ }^{24}$ Provocative as this may sound, it parallels myriad similar Arabist nuggets and a number of Arab nationalist slogans arguing that only a Muslim can be a true Arab. ${ }^{25}$

It seems that in the contemporary era of Lebanon's political breakdown the Maronites are, however labeled or libeled, the core problem of the country's ongoing crisis and disintegration; but they are also the problem's only solution. While personal ambitions and political views were not bridged within the fold of the Maronite community, Lebanon was huddling under the sectarian cloud of Muslim-Christian rifts and rivalries. A penetrating and revealing repartee between Sleiman Frangiyeh and Abu Arz speaks to the fundamental Maronite conundrum and the core of its substance. In a conversation that took place in Antelias just north of Beirut in 1978, Frangiyeh told Abu Arz "we have to divide Lebanon because a country with two heads [Christian and Muslim] is not viable." Abu Arz thought to himself that "had the first head been powerful and dignified enough, a second head would have never been afforded a fighting chance to grow and challenge the real head." Then he spoke:

you cannot divide the country; at least not in a geographical sense. Christian, Muslim, and Druze villages are in close proximity to each other, and a number of Lebanese localities have mixed populations. Besides, the day you divide Lebanon is the day I will move to live on the Muslim side; because in your proposed Maronite-Christian state the people will soon be at each other's necks.

Not long after this interchange, the massacre of Ehden took place.

\footnotetext{
${ }^{22}$ In a symbolic and small proof of this religious notion was the conversion by some Muslim members of the Guardians of the Cedars party to Christianity. This fascinating phenomenon was noted in earlier Lebanese history.

${ }^{23}$ According to a certain view, the great and legendary Fakhr al-Din II in the seventeenth-century, who united Lebanon from Aleppo to Acre, left the Druze faith and adopted Christianity.

${ }^{24}$ Hilal Khashan, Inside the Lebanese Confessional Mind (London: University Press of America, 1992$), 96$.

${ }^{25}$ Baathist politician and academic Abdul-Rahman al-Bazzaz famously wrote, "there could in no way be a contradiction between Arabism and Islam." Another Arab nationalist with Marxist leanings, the Egyptian Adel Hussein, maintained, "Islam is the other face of Arabism."
} 
Lebanon's calling in the service of liberty and humanism was abducted and despoiled by the vilest and dirtiest of leaders. By contrast, Hezbollah upheld arguably the dirtiest of causes, weaving bigotry, sectarianism, misogyny, and creed of war and death, yet it was led by competent, focused, and dedicated leaders. By way of intimidation, armed bullying, and political intrigue, Hezbollah effectively rose to preeminence. Today, with veto power and an arsenal dwarfing that of the regular Lebanese military, Hezbollah all but dominates the whole of Lebanon. Meanwhile, Lebanon's Christians continue quibbling and squabbling and growing weaker. It is the absence of leadership that has brought down the House of Lebanon. The people are good; the people are always good; but the manic shepherds are the ones to blame for the destruction of Lebanon and its people. ${ }^{26}$

Perhaps, a succinct parable related by Abu Arz best describes the Maronites' situation today. In the beginning, said Abu Arz, the Maronite leaders were bickering over the wobbly seat of the presidency; the seat had only three legs, but they still fought over it; today the seat has but a single atrophied leg left, and they fight over it still—specially Aoun, Geagea, and perhaps even Amin Gemayel. Lebanon cannot be healed of its malignant political malaise if the Lebanese close the intra-Maronite wound but leave the germs and puss festering inside. They need to clean out everything; chastise the guilty, reconcile the wayward, expel the enemies, return the exiled, and rebuild Lebanon on foundations of faith and purity for the entire Lebanese people. Ignoring the past is not the way to embark on a healthy hopeful future.

Maybe when they stop bickering for the seat of power, they will be able to ascend the throne of Maronite glory as in days past. Then Lebanon and its splendid history, home to a breed of rugged mountaineers and intrepid mariners, will fulfill its mission in its native and universal homelands-Lebanon and the "Lebanese universe" (le monde libanais, to use Saïd Akl's expression.) As Antoun Ghattas Karam wrote metaphorically: "Je suis en effet l'Orient et je suis l'Occident, je suis le carrefour et je suis le virage",27 (I am indeed the East and I am the West, I am the crossroads and I am the curve).

Lebanon has been the home of exceptional intellectual innovations in the modern Middle East. The list of its cultural and political contributions includes Arabism, the idea of Greater Syria, Greater Lebanon, Mediterraneanism, Liberalism, Secularism, and cosmopolitanism, all of which were formulated and disseminated by Lebanese thinkers, poets, and literati throughout the

\footnotetext{
${ }^{26}$ Likely more fact than fable magnifying the point is the following story, related by Hafez al-Assad to Camille Chamoun during a visit by Lebanese Christian political chiefs to Damascus in the 1970s. The joke begins with the Maronite leaders having died and in heaven St. Peter calls them to meet with Jesus. Jesus asks Frangiyeh why he killed Christians at the church in Mizra'a near Zghorta in 1957: "Because they shot at me" he answers. Jesus then asks Chamoun why he killed Christians in 1958 in the Civil War: "Because Nasser organized a rebellion against me" he answers. Jesus then asks Gemayel why he killed Christians in Ehden and Safra: "Because...." he answers. Then Jesus asks Abu Arz why he killed Palestinians at Tel el-Zaatar. No answer. He is asked the question three times, but there is no answer. "Why don't you answer Jesus?" St. Peter asks Abu Arz. "Because Jesus is a Palestinian, and I don't speak with Palestinians," Abu-Arz answers. (Abu Arz, we should add, is a true Christian.)

${ }^{27}$ Antoun Ghattas Karam, Le Livre De Abdullah (Paris: Editions UNESCO, 1993), 45.
} 
nineteenth and twentieth centuries. By contrast, subjugated to Islamist, Syrianist, and Arabist orthodoxies, Lebanon's diversity, humanism, and cosmopolitan hybridity were badly damaged, and the country's humanist historical mission was stunted and derailed. This breached and transgressed country lost its compass and its calling in the whirlpool of regional revolutions and imperial rapacity. And in line with a mangled mix of alien and spiteful ideologies, the emerging image of the Lebanese as deceivers, liars and murderers who indulge their egos and care nothing for principle and homeland, became a sad fleeting interlude, unrepresentative of the true national portrait of this ancient land and its people. The phoenix of Phoenician mythology, the fabulous firebird that self-immolates only to re-emerge rejuvenated from its ashes, will perhaps reappear in the political future of a Lebanon rising from the inferno of destruction and despair. Even the pessimist would be justified hoping for this, against hope. For, besides history, little else is permanent or final in the Middle East wrote Charles Malik some thirty years ago: but just as "you will have found Jews about forty centuries ago and ever since," so will you have found Christians in Lebanon some twenty centuries ago and since, and so will you find them there twenty centuries from now, "whatever the [looming] fortunes of states, cultures, tongues, and races." 28 And history will be the measure of this prophecy.

* Mordechai Nisan earned his Ph.D. in Political Science from McGill University in Montreal. He taught Middle East Studies at the Hebrew University of Jerusalem for 35 years, and at other academic institutions in Israel, while cultivating a wide-ranging interest in the peoples and religions of the region. Among his writings: Toward a New Israel: The Jewish State and the Arab Question (1992), Minorities in the Middle East (2002), The Conscience of Lebanon: A Political Biography of Etienne Sakr (Abu-Arz) (2003), and most recently Only Israel West of the River (2010). Dr. Nisan continues to lecture and write on contemporary issues concerning the Mideast and its multi-faceted problems.

\footnotetext{
${ }^{28}$ Malik, Lebanon and the World, 21-22.
} 